\title{
Mortality of workers potentially exposed to epichlorohydrin
}

\author{
P E Enterline, V Henderson, G Marsh
}

\begin{abstract}
An epidemiological study was undertaken to determine whether the animal carcinogen, epichlorohydrin (ECH), produces cancer in man. A total of 863 workers with probable exposure to ECH at two chemical plants during 1948-65 were followed up for deaths up to 1983. Twenty years or more after first exposure the all cancer SMR was $112 \cdot 2$ (22 deaths) and the SMR for leukaemia was 500.0 (three deaths), which is statistically significant. All cancer, leukaemia, and most other causes of death were related to estimated levels of exposure to ECH, except violence. The most consistent (both plants) relation was between exposure level and heart disease. Overall, the heart disease SMR 20 years or more after first exposure was $39 \cdot 2$ (five deaths) for low exposure and 105.4 (17 deaths) for high exposure. Limited evidence of a cardiovascular disease relation to ECH production in one other epidemiological study is supported by this study. Allyl chloride used in the production of ECH may play a part. The relation of heart disease and exposure does not appear to be an artifact, although the fact that many other causes of death were also related to exposure argues against a causal relation.
\end{abstract}

\footnotetext{
"What the causes hereof are we shall not trouble ourselves to conjecture, only we shall desire that travelers would inquire whether it be the same in other countries ..." John Graunt, 1662.
}

Epichlorohydrin (ECH) is a chemical used in manufacturing glycerine, epoxy resins, insecticides, agricultural chemicals, coatings, adhesives, and many other products. It was originally studied as a possible anaesthetic agent but found to be unsuitable due to its irritant properties. ${ }^{1}$ In the 1970 s ECH was recognised as a possible carcinogenic substance

Department of Biostatistics, Graduate School of Public Health, University of Pittsburgh, Pittsburgh, PA 15261, USA

P E Enterline, V Henderson, G Marsh based on structural grounds. ${ }^{2}$ Subsequently, it was shown to be a direct acting carcinogenic agent in animal inhalation studies. ${ }^{3}$ In rats ECH causes infertility in a manner similar to alphachlorohydrin, a compound used commercially for rat sterilisation. ${ }^{4}$ In man it has been reported to cause genetic damage. ${ }^{5}$ $\mathrm{ECH}$ is one of the most widely studied chemicals in occupational genetic monitoring. ${ }^{6}$ The International Agency for Research on Cancer has classified ECH as a possible human carcinogen. ${ }^{7}$

In 1976, at the request of the Shell Oil Company, one of us (PE) assembled a cohort of 863 workers ever employed at two Shell chemical plants and with probable exposure to ECH. Some data on the mortality experience of this cohort have been published previously. ${ }^{8}$ We are aware of five other epidemiological studies of workers exposed to ECH. Two of these are case-control studies of lung cancer in chemical plants that produced or used ECH. ${ }^{910}$ Neither was considered positive for lung cancer. Three are cohort studies. One was a 1979 unpublished study by Shallenberger et al from the Dow Chemical Company. This study was considered negative for cancer but dealt with only 12 total deaths. A cohort study by the European ECH and epoxy resin producers was also considered negative for cancer but dealt with only 10 total deaths. ${ }^{11}$ The third cohort study was considered positive for lung cancer with four deaths from lung cancer observed among 44 men with probable exposure to $\mathrm{ECH}$ whereas only 0.91 were expected. ${ }^{12}$ There have also been two studies of testicular function among workers exposed to ECH, one at the two Shell chemical plants in the study reported here and one at a plant operated by the Dow Chemical Company. ${ }^{1314}$ Both were considered negative.

This is a report on the mortality experience of the 863 workers we identified as having probable exposures to ECH at the two Shell chemical plants. Follow up of these cohorts was for 1948-83 and was essentially complete, with only two of the workers lost to follow up and for those known to be dead only one had cause of death unknown. One of the chemical plants is at Deer Park, Texas, where production of ECH started in May 1948 and the other at Norco, Louisiana, where production of ECH started in April 1955. At Deer Park the cohort consisted of those male 
workers with an estimated three or more months in departments where exposure to $\mathrm{ECH}$ could have occurred from the date of production start up to the end of 1965. Departments chosen were the glycerine department where crude ECH was produced from allyl chloride and crude $\mathrm{ECH}$ was used to produce glycerine, a department that finished $\mathrm{ECH}$ before storage for other uses, the ECH shipping department, and the epoxy resins department where finished ECH was used. This Deer Park cohort was developed from quarterly departmental seniority lists with demographic information obtained from personnel records. * Shift foremen were identified through personal knowledge of plant personnel. Maintenance workers were not included since they could not be identified with any single department. At Norco the cohort exposed to ECH was identified from personnel records and included both hourly paid and salaried male workers with six months or more exposure as at the end of 1965. Maintenance workers who were employed for six months or more during the period April 1955 to July 1957 were included since this plant produced only ECH during that period.

In 1976, after the worker cohorts were identified, each worker was classified in terms of his level of $\mathrm{ECH}$ exposure. The classification was heavy, moderate, light, nil, or unknown and was based on assessments made by industrial hygiene personnel and by current and former employees meeting at a workshop session. Employees were selected who were likely to be personally acquainted with the workers and with the jobs they performed. Firstly, all jobs were classified as heavy, moderate, light, or nil, then names were read from seniority lists and the group tried to remember the worker and the job he held. Workers were assigned to the job with the highest level of exposure.

As a background for estimating exposure levels, historical industrial hygiene data were available as were data on process and production changes, ventilation changes, and work practices. Because of its distinctive odour it was possible in many instances to recall times and units where odour thresholds were exceeded. Also, because liquid $\mathrm{ECH}$ is an irritant to the skin and mucosal wall and the vapours are irritating to eyes, nose, and throat high exposure could frequently be recalled. During early production periods exposures were sufficiently high to be a source of irritation (10-20 ppm). There was an exchange between workshop personnel at Deer Park and at Norco to ensure uniform classification. In general the estimation process was thought to be satisfactory by those participating.

The two cohorts were followed up for deaths

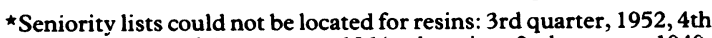
quarter, 1962, and 1st quarter, 1964; glycerine: 2nd quarter, 1949, 2nd quarter, 1950, 3rd quarter, 1952, 1st and 2nd quarter, 1963; shipping: 4th quarter, 1962. through 1983 using United States social security? files, Texas state drivers licence files, city telephone $\overrightarrow{\bar{F}}$ directories, follow up by a commercial tracing organisation, contacts with friends and relatives, clearance with the United States National Death Index, clearance with the death index maintained by the Texas State Health Department, and information $\Omega$ provided directly by the Shell Oil Company. Data $\infty$ were analysed using the occupational cohort mor- $\overrightarrow{0}$ tality anaiysis program. ${ }^{15}$

Expected deaths for 1948-83 for cancer and for 1960-83 for other causes of death were calculated from the mortality and population data system (MPDS) maintained by the department of biostatistics, Graduate School of Public Health, University of Pittsburgh. ${ }^{16}$ This system provides information on each death from cancer that occurred in the United States starting in 1950 but for non-cancer deaths data are only available since 1962 . For this reason where expected deaths for causes other than cancer were calculated for 1948-59 United States vital statistics data were used. For 1960-1 non-cancer expected deaths were estimated from the MPDS data for 1962-4 and for 1948-9 deaths from cancer were calculated from MPDS data for 1950-4. Deficits and excesses in mortality are expressed as standardised mortality ratios (SMRs). (SMRs are the ratio of observed deaths to expected deaths based on some reference population $(\times 100)$. Expected deaths are based on white male death rates.)

When only the follow up period 1960-83 was examined local death rates were used in calculating expected deaths. For Deer Park, Texas, these are for Harris County, the county where the Deer Park plant is located. For Norco, Louisiana, the home addresses of workers in the study were examined and over $90 \%$ had home addresses in the parishes of Jefferson, St Charles, St James, St John the Baptist, and Tangupoloa. The mortality experience in these parishes was used to calculate expected deaths for Norco workers.

\section{Results}

Table 1 shows observed deaths and SMRs for the $\mathcal{O}$ Deer Park and Norco cohorts combined for four follow up periods. These represent three earlier $\mathrm{N}$ follow up reports to the Shell Oil Company and the $\omega$ follow up reported here. The cause of death of $\widetilde{\sigma}$ primary interest was cancer of the respiratory sys-읃 tem. Table 1 shows that the SMR for this condition $\mathbb{\&}$ was raised in the report for the period up to 1977 but? that the SMR has since declined; in the report respiratory cancer was a cause for concern. Since the $\frac{O}{\mathbb{D}}$

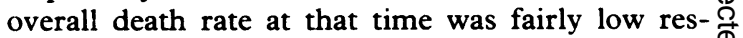
piratory cancer contributed heavily to total deaths.

Table 1 shows how mortality of a cohort can $\bar{\gamma}$ change as follow up continues. The all cause SMR 8 rose from 44.9 up to 1975 to 67.3 up to 1983 . This 
Table 1 Comparison of observed deaths and SMRs† in four reports on workers with probable exposure to epichlorohydrin

\begin{tabular}{|c|c|c|c|c|c|c|c|c|}
\hline \multirow[b]{3}{*}{ Cause of death } & \multicolumn{8}{|c|}{ Years cohort followed up } \\
\hline & \multicolumn{2}{|c|}{$1948-75$} & \multicolumn{2}{|c|}{$1948-77$} & \multicolumn{2}{|c|}{$1948-79$} & \multicolumn{2}{|c|}{$1948-83$} \\
\hline & Obs & $S M R$ & Obs & $S M R$ & Obs & $S M R$ & Obs & $S M R$ \\
\hline All causes & 37 & $44 \cdot 9 \star \star$ & 52 & $53 \cdot 4^{\star \star}$ & 65 & $56 \cdot 2^{\star \star}$ & 93 & $67 \cdot 3 \star \star$ \\
\hline All cancers & 7 & $50 \cdot 8$ & 14 & $80 \cdot 0$ & 16 & 73.6 & 28 & 91.9 \\
\hline Buccal cavity \& pharynx & 0 & - & 0 & - & 0 & - & 0 & - \\
\hline Digestive system & 0 & - & 2 & $52 \cdot 5$ & 2 & $42 \cdot 3$ & 3 & $46 \cdot 6$ \\
\hline Respiratory system & 5 & $97 \cdot 8$ & 9 & $131 \cdot 6$ & 10 & $114 \cdot 4$ & 14 & $110 \cdot 7$ \\
\hline Urinary system & 0 & - & 0 & - & 0 & - & 1 & $80 \cdot 0$ \\
\hline Leukaemias & 1 & $125 \cdot 0$ & 2 & $224 \cdot 7$ & 2 & $194 \cdot 2$ & 3 & 243.9 \\
\hline Lymphomas & 0 & - & 0 & - & 0 & - & 0 & - \\
\hline All other cancer & 1 & $35 \cdot 6$ & 1 & $29 \cdot 8$ & 2 & $50 \cdot 4$ & 7 & 116.9 \\
\hline Stroke & 2 & $63 \cdot 7$ & 2 & $50 \cdot 5$ & 3 & $60 \cdot 6$ & 7 & $130 \cdot 4$ \\
\hline All heart disease & 16 & $58 \cdot 0^{\star}$ & 23 & $69 \cdot 2$ & 28 & $68 \cdot 7^{\star}$ & 37 & $72 \cdot 2^{\star}$ \\
\hline Coronary heart disease & 16 & $70 \cdot 0$ & 22 & 83.9 & 27 & $84 \cdot 3$ & 33 & $75 \cdot 7$ \\
\hline Other heart disease & 0 & - & 1 & $14 \cdot 3^{\star}$ & 1 & $11 \cdot 4^{\star \star}$ & 4 & $52 \cdot 4$ \\
\hline Accidents & 5 & $31 \cdot 5^{\star \star}$ & 6 & $35 \cdot 3^{\star \star}$ & 9 & $49 \cdot 5^{\star}$ & 10 & 65.9 \\
\hline Suicide & 2 & $57 \cdot 0$ & 2 & $47 \cdot 4$ & 2 & 41.9 & 2 & $38 \cdot 1$ \\
\hline All other causes & 5 & $34 \cdot 6^{\star \star}$ & 5 & $29 \cdot 6^{\star \star}$ & 7 & $34 \cdot 6^{\star \star}$ & 9 & $34 \cdot 1 \star \star$ \\
\hline
\end{tabular}

*Significant at $5{ }^{\circ}{ }_{0}$ level; ${ }^{\star \star}$ significant at $1^{\circ}{ }_{0}$ level.

+SMRs based on death rates for Texas and Louisiana except for 1948-59, which is based on state rates for cancer but United States rates for causes other than cancer.

type of increase appears to be due to an initial selection against unhealthy workers with the effect of this on SMRs diminishing as time progresses. ${ }^{17}$ SMRs for the leukaemias have been consistently raised, although numbers of deaths are small. There is a sharp increase in the "all other cancer" category in the current follow up period and in deaths from stroke. Of the five additional all other cancer deaths in the current follow up one was a brain cancer, one a melanoma, one prostatic, and two were of unspecified site.

Of the 93 deaths in table 1,90 occurred during 1960-83. To use the MPDS fully to calculate expected deaths in the material that follows, the follow up period will be limited to 1960-83. Use of the MPDS permits local area mortality to be used to calculate expected deaths. This is thought to be desirable since it tends to correct the SMRs for geographic variations in cultural, social, and economic factors associated with mortality. Thus the mortality experience of the workers is being compared with the mortality experience of a local population from which the workers were drawn. Expected deaths are based on white male death rates since the study population consisted only of men, almost all of whom were white.

Table 2 shows observed deaths and SMRs for a detailed cause of death listing by time since first exposure to ECH. The total number of workers in table 2 is 859 as compared with 863 in table 1 , reflecting the three deaths that occurred before 1960 plus one worker lost to follow up before 1960. For the total cohort, the death rate for all causes of death is statistically significantly low and for no cause of death is there a statistically significant excess. There are no deaths from non-malignant respiratory disease or cirrhosis of the liver and a low death rate for external causes and for heart disease. The deficits for non-malignant respiratory disease, cirrhosis of the liver, heart disease, and external causes are statistically significant. Taken together the deficits in these four causes of death suggest a group of workers with a fairly healthy lifestyle.

There is an increase in SMRs by time since first exposure for all causes of death and for all malignant neoplasms and a statistically significant excess in leukaemia 20 years or more since first exposure. For respiratory cancer, however, the SMR declined with time since first exposure and this is true when workers from Deer Park and Norco are examined separately (not shown). The SMR also declined with time since first exposure for cerebrovascular disease. The fact that the SMR for respiratory cancer was highest less than 20 years since first exposure argues against a causal relation for ECH. For Deer Park the possibility that exposures before exposure to $\mathrm{ECH}$ are involved in an excess has been explored elsewhere. ${ }^{8}$ Curiously, all deaths from cancer that occurred less than 20 years from first exposure were deaths from lung cancer.

Table 3 compares the mortality experience at Deer Park and Norco for an abbreviated cause of death listing. Only those causes of death are shown in table 3 where two or more deaths were observed in the total cohort. The pattern of mortality in the two plants was similar, although numbers for most of the causes shown are small. SMRs for all causes of death are statistically significantly low and almost identical; those for prostatic cancer and leukaemia are in excess in both plants but these are based on small numbers of deaths.

Table 4 shows that 20 years or more since first 
Table 2 Observed deaths and SMRs $\dagger$ by time since first exposure for workers with probable exposure to epichlorohydrin, Deer Park and Norco, 1960-83

\begin{tabular}{|c|c|c|c|c|c|c|}
\hline \multirow[b]{3}{*}{ Cause of death (ICD 8th rev codes) } & \multicolumn{6}{|c|}{ Time since first exposure (y) } \\
\hline & \multicolumn{2}{|l|}{ Total } & \multicolumn{2}{|l|}{$<20$} & \multicolumn{2}{|l|}{$\geqslant 20$} \\
\hline & Obs & $S M R$ & Obs & $S M R$ & Obs & $S M R$ \\
\hline All causes of death & 90 & $64 \cdot 7^{\star}$ & 32 & $51 \cdot 3 \star \star$ & 58 & $75 \cdot 6^{\star}$ \\
\hline Tuberculosis $(10-19)$ & 0 & - & 0 & - & 0 & $\overline{100}$ \\
\hline All malignant neoplasms (140-209): & 28 & $90 \cdot 8$ & 6 & $53 \cdot 4$ & 22 & $112 \cdot 2$ \\
\hline Buccal cavity \& pharynx $(140-149)$ & 0 & $-\bar{c}$ & 0 & - & 0 & $\overline{720}$ \\
\hline Digestive system and peritoneum $(150-159)$ : & 3 & $46 \cdot 7$ & 0 & - & 3 & $\begin{array}{r}73.9 \\
73.9\end{array}$ \\
\hline Large intestine (153) & 2 & $93 \cdot 0$ & 0 & - & 2 & $147 \cdot 0$ \\
\hline Rectum (154) & 0 & - & 0 & - & $\mathbf{0}$ & - \\
\hline Biliary passages \& liver primary $(155,156)$ & 0 & $\overline{6}$ & 0 & - & 0 & $\overline{102}$ \\
\hline Pancreas (157) & 1 & $66 \cdot 7$ & 0 & - & 1 & $103 \cdot 1$ \\
\hline Other digestive cancer & 0 & - & 0 & - & 0 & - \\
\hline Respiratory system (160-163): & 14 & $104 \cdot 5$ & 6 & $135 \cdot 4$ & 8 & $89 \cdot 2$ \\
\hline Larynx (161) & 0 & - & 0 & - & 0 & - \\
\hline Bronchus, Trachea, \& Lung (162) & 14 & $108 \cdot 4$ & 6 & $140 \cdot 5$ & 8 & $92 \cdot 6$ \\
\hline Other respiratory cancer & 0 & $\overline{50}$ & 0 & - & 0 & $-\overline{2}$ \\
\hline Prostate (185) & 2 & $215 \cdot 0$ & 0 & 一 & 2 & $270 \cdot 3$ \\
\hline Kidney (189.0-189.2) & 1 & $135 \cdot 1$ & 0 & - & 1 & $217 \cdot 4$ \\
\hline Bladder $\&$ other urinary organs $(188,189.9)$ & 0 & $-\overline{0}$ & $\mathbf{0}$ & 一 & 0 & $\overline{256 \cdot 4}$ \\
\hline Melanoma of skin $(172.0-172.4,172.6-172.9)$ & 1 & 138.9 & $\mathbf{0}$ & - & 1 & $256 \cdot 4$ \\
\hline Central nervous system $(191,192)$ & 1 & $85 \cdot 5$ & $\mathbf{0}$ & - & 1 & $161 \cdot 3$ \\
\hline All lymphatic \& haematopoietic tissue (200-209) & 3 & $100 \cdot 0$ & 0 & - & 3 & $181 \cdot 8$ \\
\hline Lymphosarcoma \& reticulosarcoma $(200)$ & 0 & - & 0 & - & 0 & - \\
\hline Hodgkins disease (201) & 0 & - & 0 & - & 0 & - \\
\hline Leukaemia \& aleukaemia (204-207) & 3 & $254 \cdot 2$ & 0 & - & 3 & $500 \cdot 0^{\star}$ \\
\hline All other lymphopoietic tissue & 0 & - & 0 & - & 0 & - \\
\hline All other cancer & 3 & $101 \cdot 7$ & 0 & - & 3 & $174 \cdot 4$ \\
\hline Diabetes mellitus (250) & 0 & - & 0 & - & 0 & - \\
\hline Cerebrovascular disease $(430-438)$ & 7 & 128.9 & 4 & $168 \cdot 1$ & 3 & $98 \cdot 4$ \\
\hline \multicolumn{7}{|l|}{ Heart disease $(390-398,400.1,400.9,402,404$, } \\
\hline $410-414,420-429)$ & 36 & $67 \cdot 9 \star$ & 14 & $63 \cdot 6$ & 22 & $70 \cdot 9$ \\
\hline Rheumatic heart disease (390-398) & 0 & - & 0 & - & $\mathbf{0}$ & - \\
\hline Ischaemic heart disease $(410-414)$ & 32 & $72 \cdot 3$ & 14 & $71 \cdot 1$ & 18 & $73 \cdot 3$ \\
\hline \multirow{2}{*}{\multicolumn{7}{|c|}{ Hypertension $w / 0$ heart disease $(400.0,400.2,400.3$, }} \\
\hline & & & & & & \\
\hline $\begin{array}{l}401,403) \\
\text { Non-malignant respiratory disease }(460-519) \text { : }\end{array}$ & $\begin{array}{l}0 \\
0\end{array}$ & 二 & $\begin{array}{l}0 \\
0\end{array}$ & $\bar{z}$ & $\begin{array}{l}0 \\
0\end{array}$ & 二* \\
\hline Influenza \& pneumonia $(470-474,480-486)$ & 0 & - & 0 & - & 0 & - \\
\hline Bronchitis, emphysema, asthma (490-493) & 0 & - & 0 & - & 0 & - \\
\hline Bronchitis $(490,491)$ & 0 & - & 0 & - & 0 & - \\
\hline Emphysema (492) & 0 & - & 0 & - & 0 & - \\
\hline Asthma (493) & 0 & - & 0 & - & $\mathbf{0}$ & - \\
\hline Other non-malignant respiratory disease & 0 & - & 0 & - & $\mathbf{0}$ & - \\
\hline Ulcer of stomach and duodenum (531-533) & 1 & $172 \cdot 4$ & 0 & - & 1 & $476 \cdot 2$ \\
\hline Cirrhosis of liver (571) & 0 & - $\star \star$ & 0 & - & 0 & - \\
\hline Nephritis \& nephrosis (580-584) & 0 & - & 0 & - & 0 & - \\
\hline All external causes of death $(800-999)$ & 12 & $50 \cdot 4^{\star}$ & 7 & $45 \cdot 2$ & 5 & $59 \cdot 9$ \\
\hline Accidents (800-949): & 10 & $69 \cdot 5$ & 6 & $60 \cdot 9$ & 4 & $88 \cdot 3$ \\
\hline Motor vehicle accidents $(810-823)$ & 6 & $86 \cdot 3$ & 3 & $61 \cdot 7$ & 3 & $142 \cdot 8$ \\
\hline All other accidents & 4 & $53 \cdot 8$ & 3 & $60 \cdot 0$ & 1 & $41 \cdot 2$ \\
\hline Suicide $(950-999)$ & 2 & $39 \cdot 4$ & 1 & 33.0 & 1 & $48 \cdot 8$ \\
\hline Homicide \& other external causes & 0 & - & 0 & - & 0 & - \\
\hline All other causes of death & 5 & $45 \cdot 3$ & 1 & $21 \cdot 0$ & 4 & $63 \cdot 8$ \\
\hline Unknown causes & 1 & & 0 & & 1 & \\
\hline Total No of workers & 859 & & 859 & & 814 & \\
\hline Person-years & 19681 & & 1314 & & $6537 \cdot 1$ & \\
\hline
\end{tabular}

exposure the pattern of SMRs is similar in Deer Park and Norco. The category all malignant neoplasms is slightly in excess in both plants and the excess is in prostatic cancer and leukaemia. Death rates for all causes, heart disease, and external causes are low in both plants.

Of 444 workers from Deer Park observed 20 years or more since first exposure, $376(85 \%)$ could be classified by level of exposure, whereas of 370 workers from Norco observed 20 years or more since first exposure, $342(92 \%)$ could be so classified. For $\stackrel{?}{?}$ Deer Park, of 376 workers classified as to exposure 0 level, $62 \%$ were classified as moderate to heavyo whereas for Norco, of 342 workers that could be classified, only $33 \%$ were classified as moderate to $\mathbb{\nabla}$ heavy. Since there was an attempt to make the $\frac{0}{\sigma}$ exposure classification comparable this may reflect lower exposures at Norco. 
Table 3 Observed and expected deaths and SMRs† for workers with probable exposure to epichlorohydrin, $1960-83$

\begin{tabular}{|c|c|c|c|c|c|c|}
\hline \multirow[b]{2}{*}{ Cause of death (ICD 8th rev codes) } & \multicolumn{3}{|c|}{ Deer Park } & \multicolumn{3}{|l|}{ Norco } \\
\hline & Obs & $\operatorname{Exp}$ & $S M R$ & Obs & $\operatorname{Exp}$ & $S M R$ \\
\hline All causes of death & 53 & $81 \cdot 79$ & $64 \cdot 8^{\star \star}$ & 37 & $57 \cdot 23$ & $64 \cdot 6 \star \star$ \\
\hline $\begin{array}{l}\text { All malignant neoplasms }(140-209) \text { : } \\
\text { Digestive system \& peritoneum }(150-159) \\
\text { Respiratory system }(160-163) \\
\text { Prostate (185) } \\
\text { Leukaemia \& aleukaemia (204-207) } \\
\text { All other cancer } \\
\text { Cerebrovascular disease }(430-438) \\
\text { Heart disease (380-398, 400.1, 402, 404, 410-414, 420-42 } \\
\text { All external causes }(800-999) \\
\text { All other causes } \\
\text { Unknown causes } \\
\text { Total No of workers } \\
\text { Person-years }\end{array}$ & $\begin{array}{r}17 \\
2 \\
8 \\
1 \\
2 \\
4 \\
5 \\
22 \\
6 \\
3 \\
0 \\
470 \\
10756 \cdot 4\end{array}$ & $\begin{array}{r}18.37 \\
3.84 \\
8.21 \\
0.60 \\
0.70 \\
5.02 \\
3.13 \\
30.46 \\
13.85 \\
15.98\end{array}$ & $\begin{array}{c}92.5 \\
52 \cdot 1 \\
97.5 \\
166.4 \\
286.5 \\
79 \cdot 4 \\
160 \cdot 0 \\
72 \cdot 2 \\
43.3^{\star} \\
18.8^{\star \star}\end{array}$ & $\begin{array}{r}11 \\
1 \\
6 \\
1 \\
1 \\
2 \\
2 \\
14 \\
6 \\
3 \\
1 \\
389 \\
8925 \cdot 3\end{array}$ & $\begin{array}{r}12.46 \\
2.58 \\
5 \cdot 19 \\
0.33 \\
0.48 \\
3.88 \\
2.30 \\
22.58 \\
9.98 \\
9.91\end{array}$ & $\begin{array}{r}88 \cdot 3 \\
38 \cdot 7 \\
115 \cdot 5 \\
303 \cdot 4 \\
210 \cdot 4 \\
51.6 \\
86.9 \\
62.0 \\
60 \cdot 1 \\
30.3^{\star}\end{array}$ \\
\hline
\end{tabular}

${ }^{\star} \mathrm{p}<0.05 ;{ }^{* *} \mathrm{p}<0.01$.

†SMRs based on local expected deaths.

Table 5 shows the mortality experience 20 years or more since first exposure for the 376 workers at Deer Park for whom exposure levels could be estimated. For most causes of death there is a direct relation between SMRs and level of exposure. The contrast for malignant neoplasms is statistically significant ( $p$ $<0.05$ ). The raised SMR for malignant neoplasms in the higher exposure group is due partly to an excess in deaths from leukaemia. For heart disease, while an SMR of 54.4 in the nil to light group seems low it does not differ much from a SMR of 51.1 (42 deaths) calculated for the entire chemical plant for male workers 20 years or more from onset: of employment (G Marsh, et al, unpublished report) so that the SMR of 101.6 in the higher exposure group is unusual. It is statistically significantly different from the SMR of $51 \cdot 1$ for the entire chemical plant $(p$ $<0.05$ ).

Table 6 shows data as in table 5 but for Norco. Here results are similar to those for Deer Park, except that there is no exposure relation for malignant neoplasms. None of the exposure contrasts in table 6 is statistically significant. There is a statistically significant deficit in heart disease mortality in the lower exposure group.

Table 7 combines tables 5 and 6 and shows the relation between probable exposure to epichlorohydrin and selected causes of death when the two study plants are combined. There is a direct relation between level of exposure and most major causes of death except external causes. The differences for all causes and for heart disease approach statistical significance $(p<0.07)$. The respiratory cancer relation with exposure is due almost entirely to the relation at Deer Park shown in table 5. The respiratory cancer SMRs for the higher exposure groups in tables 5, 6, and 7 do not differ much from a SMR of $92 \cdot 1$ for respiratory cancer for white men 20 years or more from onset of employment for the entire Deer Park chemical complex (19 deaths) (G

Table 4 Observed and expected deaths and SMRs† 20 years or more since first exposure for workers with probable exposure to epichlorohydrin

\begin{tabular}{|c|c|c|c|c|c|c|c|}
\hline \multirow[b]{2}{*}{ Cause of death (ICD 8th rev codes) } & \multicolumn{4}{|c|}{ Deer Park } & \multicolumn{3}{|l|}{ Norco } \\
\hline & Obs & $\operatorname{Exp}$ & $S M R$ & & Obs & $E x p$ & $S M R$ \\
\hline All causes of death & 40 & $50 \cdot 59$ & $79 \cdot 1$ & & 18 & $26 \cdot 11$ & 68.9 \\
\hline $\begin{array}{l}\text { All malignant neoplasms }(140-209) \text { : } \\
\text { Digestive system \& peritoneum (150-159) } \\
\text { Respiratory system (160-163) } \\
\text { Prostate (185) } \\
\text { Leukaemia \& aleukaemia (204-207) } \\
\text { All other cancer } \\
\text { Cerebrovascular disease }(430-438) \\
\text { Heart disease ( } 380-398,400.1,402,404,410-414,420-429 \\
\text { All external causes }(800-999) \\
\text { All other causes } \\
\text { Unknown causes } \\
\text { Total No of workers } \\
\text { Person-years }\end{array}$ & $\begin{array}{r}14 \\
2 \\
5 \\
1 \\
2 \\
4 \\
3 \\
16 \\
4 \\
3 \\
0 \\
444 \\
4297 \cdot 9\end{array}$ & $\begin{array}{r}12.74 \\
2.69 \\
5.93 \\
0.50 \\
0.40 \\
3.22 \\
2.01 \\
20.09 \\
5.89 \\
9.86\end{array}$ & $\begin{array}{r}109.9 \\
74.3 \\
84.3 \\
199 \cdot 1 \\
494.4 \\
124 \cdot 2 \\
149.2 \\
79.6 \\
68.0 \\
30 \cdot 4^{\star}\end{array}$ & $\begin{array}{l}. \\
\cdots \\
\cdots \\
\cdot \\
\cdot\end{array}$ & $\begin{array}{c}8 \\
1 \\
3 \\
1 \\
1 \\
2 \\
0 \\
6 \\
1 \\
2 \\
1 \\
370 \\
2239 \cdot 2\end{array}$ & $\begin{array}{r}6.86 \\
1.37 \\
3.04 \\
0.24 \\
0.20 \\
2.01 \\
1.04 \\
10.95 \\
2.46 \\
4.80\end{array}$ & $\begin{array}{r}116.6 \\
73 \cdot 1 \\
98 \cdot 6 \\
409 \cdot 5 \\
492 \cdot 3 \\
99 \cdot 5 \\
\overline{54.8} \\
40.6 \\
41.6\end{array}$ \\
\hline
\end{tabular}

${ }^{\star} \mathbf{p}<0.05$.

†SMRs based on local expected deaths. 
Table 5 Observed and expected deaths and SMRs† 20 years or more since first exposure for workers with probable exposure to. epichlorohydrin by estimated level of exposure, Deer Park

\begin{tabular}{|c|c|c|c|c|c|c|}
\hline \multirow[b]{3}{*}{ Cause of death (ICD 8th rev codes) } & \multicolumn{6}{|c|}{ Level of exposure } \\
\hline & \multicolumn{3}{|c|}{ Nil to light } & \multicolumn{3}{|c|}{ Moderate to heavy } \\
\hline & Obs & $\operatorname{Exp}$ & $S M R$ & Obs & $\operatorname{Exp}$ & $S M R$ \\
\hline All causes of death & 7 & $14 \cdot 03$ & $49 \cdot 9$ & 31 & $31 \cdot 90$ & $97 \cdot 2$ \\
\hline $\begin{array}{l}\text { All malignant neoplasms (140-209): } \\
\text { Digestive system \& peritoneum (150-159) } \\
\text { Respiratory system (160-163) } \\
\text { Prostate (185) } \\
\text { Leukaemia \& aleukaemia (204-207) } \\
\text { All other cancer } \\
\text { Cerebrovascular disease }(430-438) \\
\text { Heart disease ( } 380-398,400.1,402,404,410-414,420-429) \\
\text { All external causes }(800-999) \\
\text { All other causes } \\
\text { Unknown causes } \\
\text { Total No of workers } \\
\text { Person-years }\end{array}$ & $\begin{array}{c}0 \\
0 \\
0 \\
0 \\
0 \\
0 \\
1 \\
3 \\
2 \\
1 \\
0 \\
143 \\
1299 \cdot 3\end{array}$ & $\begin{array}{l}3.53 \\
0.75 \\
1.64 \\
0.13 \\
0.11 \\
0.90 \\
0.52 \\
5.51 \\
1.77 \\
2.70\end{array}$ & $\begin{array}{c}- \\
- \\
- \\
- \\
\overline{-} \\
191 \cdot 2 \\
54.4 \\
113.0 \\
37.0\end{array}$ & $\begin{array}{r}13 \\
2 \\
4 \\
1 \\
2 \\
4 \\
2 \\
13 \\
1 \\
2 \\
0 \\
233 \\
2466 \cdot 0\end{array}$ & $\begin{array}{r}8 \cdot 08 \\
1 \cdot 70 \\
3 \cdot 77 \\
0.34 \\
0 \cdot 26 \\
2.01 \\
1.33 \\
12 \cdot 80 \\
3.38 \\
6 \cdot 31\end{array}$ & $\begin{array}{r}160 \cdot 9 \\
117 \cdot 4 \\
106 \cdot 1 \\
293 \cdot 7 \\
779 \cdot 0 \\
199 \cdot 0 \\
149 \cdot 8 \\
101 \cdot 6 \\
29 \cdot 6 \\
31 \cdot 7\end{array}$ \\
\hline
\end{tabular}

TSMRs based on local expected deaths.

Marsh et al, unpublished report). Thus for Deer Park, at least, it does not appear that respiratory cancer is unusually high in the higher exposure group. While in the lower exposure group a SMR of 54.8 seems low this is based on only two deaths and may have little meaning. There is a weak relation between exposure to ECH and SMRs for leukaemia. As shown in table 2, the overall excess of leukaemia was statistically significant.

\section{Discussion}

Workers who had probable exposure to $\mathrm{ECH}$ at two facilities operated by the Shell Oil Company had a favourable overall mortality experience, although with the passage of time their death rate is rising and approaching that expected in a general population. There is some evidence that these workers had a healthy lifestyle. The fact that there was a statistically significant deficit (no deaths) in non-malignant res- $\vec{\theta}$ piratory disease suggests that these workers may have smoked less than the general population. There was a. statistically significant deficit (no deaths) in cirrhosis of the liver, which suggests that these workers may have drunk less alcohol than the general population. Death rates from heart disease accidents and otherô violence were low, suggesting other behavioural $\stackrel{\Phi}{\circ}$ factors associated with healthy living.

The positive relation between exposure to $\mathrm{ECH}_{3}$ and heart disease is puzzling. If heart disease is truly increased by exposure to ECH there may not be a으. long latent period, as is likely for cancer. Less than $20 \bar{\partial}$ years since first exposure the heart disease SMR for $\frac{\mathbb{D}}{3}$ 1960-83 was 55.5 (six deaths) in the nil to light ${ }^{\circ}$ exposure group and 72.9 (seven deaths) in the 3 .

Table 6 Observed and expected deaths and SMRs† 20 years or more since first exposure for workers with probable exposure to epichlorohydrin by estimated level of exposure, Norco

\begin{tabular}{|c|c|c|c|c|c|c|}
\hline \multirow[b]{3}{*}{ Cause of death (ICD 8th rev codes) } & \multicolumn{6}{|c|}{ Level of exposure } \\
\hline & \multicolumn{3}{|c|}{ Nil to light } & \multicolumn{3}{|c|}{ Moderate to heavy } \\
\hline & Obs & $E x p$ & $S M R$ & Obs & $\operatorname{Exp}$ & $S M R$ \\
\hline All causes of death & 10 & $17 \cdot 23$ & $58 \cdot 0$ & 7 & $7 \cdot 93$ & $88 \cdot 3$ \\
\hline $\begin{array}{l}\text { All malignant neoplasms }(140-209) \text { : } \\
\text { Digestive system \& peritoneum }(150-159) \\
\text { Respiratory system }(160-163) \\
\text { Prostate (185) } \\
\text { Leukaemia \& aleukaemia }(204-207) \\
\text { All other cancer } \\
\text { Cerebrovascular disease }(430-438) \\
\text { Heart disease }(380-398,400.1,402,404,410-414,420-429) \\
\text { All external causes }(800-999) \\
\text { All other causes } \\
\text { Unknown causes } \\
\text { Total No of workers } \\
\text { Person-years }\end{array}$ & $\begin{array}{l}5 \\
0 \\
2 \\
1 \\
1 \\
1 \\
0 \\
2 \\
0 \\
2 \\
1 \\
230 \\
1434 \cdot 8\end{array}$ & $\begin{array}{l}4.53 \\
0.91 \\
2.01 \\
0.17 \\
0.13 \\
1.31 \\
0.70 \\
7.24 \\
1.58 \\
3.18\end{array}$ & $\begin{array}{c}110 \cdot 3 \\
\overline{99} \cdot 6 \\
592 \cdot 1 \\
753 \cdot 6 \\
76 \cdot 3 \\
\overline{27} \cdot 6 \star \\
\overline{62} \cdot 9\end{array}$ & $\begin{array}{c}2 \\
1 \\
1 \\
0 \\
0 \\
0 \\
0 \\
4 \\
1 \\
0 \\
0 \\
112 \\
682 \cdot 5\end{array}$ & $\begin{array}{l}2.09 \\
0.42 \\
0.93 \\
0.07 \\
0.06 \\
0.61 \\
0.31 \\
3.33 \\
0.75 \\
1.45\end{array}$ & $\begin{array}{c}95 \cdot 6 \\
240 \cdot 3 \\
107 \cdot 4 \\
- \\
- \\
- \\
\overline{120 \cdot 2} \\
133 \cdot 6 \\
-\end{array}$ \\
\hline
\end{tabular}


Table 7 Observed and expected deaths and SMRs $\dagger 20$ years or more since first exposure for workers with probable exposure to epichlorohydrin by estimated level of exposure, Deer Park and Norco

\begin{tabular}{|c|c|c|c|c|c|c|}
\hline \multirow[b]{3}{*}{ Cause of death (ICD 8th rev codes) } & \multicolumn{6}{|c|}{ Level of exposure } \\
\hline & \multicolumn{3}{|c|}{ Nil to light } & \multicolumn{3}{|c|}{ Moderate to heavy } \\
\hline & Obs & $\operatorname{Exp}$ & $S M R$ & Obs & $\operatorname{Exp}$ & $S M R$ \\
\hline All causes of death & 17 & $31 \cdot 25$ & $54 \cdot 4^{\star \star}$ & 38 & $39 \cdot 83$ & $95 \cdot 4$ \\
\hline $\begin{array}{l}\text { All malignant neoplasms }(140-209): \\
\text { Digestive system \& peritoneum }(150-159) \\
\text { Respiratory system }(160-163) \\
\text { Prostate }(185) \\
\text { Leukaemia \& aleukaemia }(204-207) \\
\text { All other cancer } \\
\text { Cerebrovascular disease }(430-438) \\
\text { Heart disease }(380-398,400.1,402,404,410-414,420-429) \\
\text { All external causes }(800-999) \\
\text { All other causes } \\
\text { Unknown causes } \\
\text { Total No of workers } \\
\text { Person-years }\end{array}$ & $\begin{array}{c}5 \\
0 \\
2 \\
1 \\
1 \\
1 \\
1 \\
5 \\
2 \\
3 \\
1 \\
373 \\
2734 \cdot 1\end{array}$ & $\begin{array}{r}8.06 \\
1.66 \\
3.65 \\
0.30 \\
0.24 \\
2.21 \\
1.22 \\
12.75 \\
3.35 \\
5.88\end{array}$ & $\begin{array}{c}62 \cdot 0 \\
\overline{54 \cdot 8} \\
333 \cdot 3 \\
416 \cdot 7 \\
45 \cdot 2 \\
82 \cdot 0 \\
39 \cdot 2^{\star} \\
59 \cdot 7 \\
51 \cdot 0\end{array}$ & $\begin{array}{r}15 \\
3 \\
5 \\
1 \\
2 \\
4 \\
2 \\
17 \\
2 \\
2 \\
0 \\
345 \\
3148 \cdot 4\end{array}$ & $\begin{array}{r}10 \cdot 17 \\
2 \cdot 12 \\
4 \cdot 70 \\
0 \cdot 41 \\
0 \cdot 32 \\
2 \cdot 62 \\
1 \cdot 64 \\
16 \cdot 13 \\
4 \cdot 13 \\
7 \cdot 76\end{array}$ & $\begin{array}{r}147.5 \\
141.5 \\
106.4 \\
243.9 \\
625.0 \\
152.7 \\
121.9 \\
105.4 \\
48.4 \\
25.8\end{array}$ \\
\hline
\end{tabular}

${ }^{*} \mathrm{p}<0.05 ;{ }^{* *} \mathrm{p}<0.01$.

†SMRs based on local expected deaths.

moderate to heavy group (not shown). This contrast is smaller than, but consistent with, that 20 years or more since first exposure.

The positive relation between $\mathrm{ECH}$ exposure level and deaths from heart disease is not an artifact due to the indirect method used to adjust death rates for age. Direct age adjustment of rates has little effect on this relation. Moreover, since the classification as to level of exposure took place before most deaths occurred, it is unlikely that bias was introduced into the classification process by knowledge of the presence of death or disease. This relation appeared in earlier reports but has grown a little stronger in more recent follow up periods so that many of the deaths responsible occurred after the exposure classification was made. While the exposure classification was probably imperfect, it was undoubtedly able roughly to rank levels of exposure so that at least some type of ordinal classification was achieved.

There could be some confounding arising from the fact that workers were assigned to their most heavily exposed job since longer work experience (and more jobs) could make such an assignment more likely than shorter worker exposure (and fewer jobs). Longer work experience could be directly associated with increases in mortality due to initial selection against unhealthy workers, with this effect diminishing with time. This is sometimes referred to as the healthy worker effect and was discussed earlier in regard to table 1. For workers in tables 5 and 6 the mean duration of work differs before 1976 in the higher $v$ the lower exposure group at Deer Park (7.5 years $v$ 5.3 years) but not at $\operatorname{Norco}(4.8$ years $v 5.0$ years $)$. At Deer Park there was also a difference in mean year of first exposure in the higher $v$ the lower exposure group (1952 $v$ 1954), probably related to the difference in mean duration of exposure. It seems unlikely that these differences could account for a healthy worker effect as large as the all cause and the heart disease SMR contrasts shown in table 5. If the healthy worker effect is indeed unimportant then the longer duration of exposure for the higher exposure group at Deer Park is supportive of a causal relation between exposure to $\mathrm{ECH}$ and heart disease mortality.

It is remotely possible that $\mathrm{ECH}$ has some effect on heart disease. Flessel et al reported on a two year follow up of 21 workers who cleaned up a 1975 spill of a subsoil fumigant 1,3-dicloropropene (DCP). ${ }^{18}$ DCP is structurally similar to ECH. Also, at that time DCP contained ECH as a stabiliser. ${ }^{19}$ Ten of the 21 workers complained of chest pain or discomfort and the two with the most severe chest pain had had cardiac catheterisation (but were found to be normal).

In the 1979 Dow Chemical Company mortality study of workers with potential exposure to ECH (discussed earlier) five deaths were from cardiovascular disease in a cohort of 553 workers and the SMR was $68 \cdot 9$. All the deaths occurred in a subgroup of 169 workers who had held at least one job in a department that produced $\mathrm{ECH}$ and where there was apparently equal exposure to both $\mathrm{ECH}$ and allyl chloride (allyl chloride is used to produce ECH). In this subgroup the cardiovascular disease SMR was 111.6. All the workers at Norco were engaged in ECH production and 213 of the 470 workers at Deer Park were at some time in the glycerine department where $\mathrm{ECH}$ was produced. Among these 213 workers at Deer Park 195 could be classified as to level of exposure with 160 having moderate to heavy exposure. The cardiovascular disease SMR for these 160 workers was $120 \cdot 7$ ( 16 deaths). For 35 workers who had nil to light exposure the cardiovascular disease SMR was 55.2 (one death). Of 257 Deer Park workers who never worked in the glycerine depart- 
ment and thus were probably not exposed to allyl chloride, 204 could be classified as to level of exposure with 88 having moderate to heavy exposure. The cardiovascular disease SMR for these 88 workers was $65 \cdot 1$ (five deaths). For 116 workers who had nil to light exposure the cardiovascular disease death rate was $\mathbf{5 1 . 6}$ (four deaths). In summary, at Deer Park the only raised cardiovascular disease SMR was for workers with moderate to heavy exposure to $\mathrm{ECH}$ and who had probable exposure to allyl chloride (SMR $=120 \cdot 7)$. All other workers had lower SMRs $(55 \cdot 2,65 \cdot 1$, and $51 \cdot 6)$. This pattern is essentially the same if observations are confined to heart disease mortality. These data support the findings in the Dow study and suggest that exposure to allyl chloride might somehow be involved in the observed heart disease dose response relation.

There is little in human or animal experience to suggest a relation between allyl chloride and cardiovascular disease. Hausler and Lenich reported reversible liver damage in workers exposed to concentrations ranging from one to $113 \mathrm{ppm}$ for 16 months. ${ }^{20}$ Ali-Zade reported that workers exposed to unknown concentrations of allyl chloride had impaired kidney function. ${ }^{21}$ Boqin et al reported pathological changes in the liver, kidney, and lungs of animals exposed to allyl chloride. ${ }^{22}$

The only statistically significant excess observed in this study was for leukaemia 20 years or more after first exposure. These deaths were investigated and found to be of differing cell types, which argues against a common aetiology. One was chronic lymphocytic, one acute granulocytic, and one acute lymphocytic. There have been no reports of leukaemia associated with exposure to ECH. Nevertheless, there is animal evidence that $\mathrm{ECH}$ causes damage to chromosomes in bone marrow cells of mice after oral or intraperitoneal administration. ${ }^{23}$ Moreover, deaths from leukaemia in the Deer Park chemical complex were concentrated in workers with probable exposure to $\mathrm{ECH}$. In the larger 1987 study of the entire Deer Park chemical complex only three deaths from leukaemia were observed (G Marsh $e t$ al, unpublished report). Two of these are in the study reported here.

Evidence for a relation between exposure to $\mathrm{ECH}$ and respiratory cancer, the likely target organ based on animal evidence, is also conflicting. When data from both plants are combined there is a clear dose response relation in workers 20 years or more since first exposure. This is, however, almost entirely due to one of the two plants studied. For that plant even in the higher exposure category the SMR was not greatly raised in relation to either the local area death rate or to the SMR observed in the entire chemical complex at Deer Park. This argues against a causal relation as does the fact that respiratory cancer SMRs did not increase with time since first exposure. Further study of relation with respiratory cancer should take smoking habits into account since these may be unusual in the cohorts of workers studied? here.

This study was supported by a contract between the $\frac{\stackrel{5}{+}}{\frac{2}{9}}$ Shell Oil Company and the University of Pittsburgh. We gratefully acknowledge the initiative and $\overline{\bar{\omega}}$. encouragement of Dr Roy Joyner, former medical ${ }_{\phi}$ director of the Shell Oil Company, Mary Ruth Jones, $\cong$ nurse epidemiologist at Shell Oil Company, whow helped develop the original cohort, Dorothy $\vec{O}$ McCraw, epidemiologist at Shell Oil Company, who helped with the follow up, and J L Rivard whow worked on the exposure assessment.

1 Van Kossa J. On epichlorohydrin. Arch Int Pharmacodyn Ther 1898;4:351-9.

2 Van Duuren BL, Katz C, Goldschmidt BM, et al. Carcino- . genicity of haloethers. II. Structure-activity relationships of + analogs of bis(chloromethyl)ether. J Natl Cancer Inst N 1972;48:1431-9.

3 Laskin S, Sellakuman AR, Kuschner M, et al. Inhalation carcinogenicity of epichlorohydrin in noninbred SpragueDawley rats. J Natl Cancer Inst 1980;4:751-7.

4 Cooper ER, Jones AR Jackson H. Effects of alpha-chlorohydrin and related compounds on the reproductive organs and $\frac{D}{O}$ fertility of the male rat. $J$ Reprod Fertil 1974;38:379-86.

5 Sram RJ, Tomatis L, Clemmesen J, et al. An evaluation of the genetic toxicity of epichlorohydrin. Mutat Res 1981;87: $\vec{\varphi}$ 299-319.

6 Dabney BJ. Cytogenetic findings on employees with potential exposure to epichlorohydrin. In: Monitoring of occupational genotoxicants. New York: Alan R Liss, 1986:59-73.

7 International Agency for Research on Cancer. Monographs on the evaluation of the carcinogenic risk of chemicals to humans. Vols $1 \overline{\bar{D}}$ to 29, suppl 4. Lyon: IARC, 1982.

8 Enterline PE. Importance of sequential exposure in the production of epichlorohydrin and isopropanol. In: Brain tumours in the chemical industry. New York Academy of Science 1982;381:344-9.

9 Hagmar L, Bellander T, Englander V, Ranstam J, Attewell R, כ Skerfving $S$. Mortality and cancer morbidity among workers in a chemical factory. Scand $J$ Work Environ Health 1986;12:545-51.

10 Bond GG, Flores GH, Shellenberger RJ, Cartmill JB, Fishbeck WA, Cook RR. Nested case-control study of lung cancer among chemical workers. Am J Epidemiol 1986;124:53-66.

11 Tassignon JP, Bos GD, Craigen AA, et al. Mortality in a European cohort occupationally exposed to epichlorohydrin (ECH). Arch Occup Environ Health 1983;51:325-36.

12 Delzell E, Macaluso M, Cole P. A follow-up study of workers at a dye and resin manufacturing plant. J Occup Med 1989;31: 273-8.

13 Milby TH, Whorton MD, Stubbs HA, et al. Testicular function $\mathrm{O}$ among epichlorohydrin workers. Br J Ind Med 1981;38:372-7. 工

14 Venable JR, McClimans CD, Flake RE, Dimick DB. A fertility $D$ study of male employees engaged in the manufacture of
glycerine. J Occup Med 1980;22:87-91.

15 Marsh GM, Preininger ME. OCMAP: a user-oriented $N$ occupational cohort mortality analysis program. American $\Omega$ Statistician 1980;34:245.

16 Marsh GM, Ehland J, Sefcik S. Mortality and population data system. University of Pittsburgh, 1987. 17 Monson RR. Observations on the healthy worker effect. J Occup
Med 1987;28:425-33.

18 Flessel P, Goldsmith JR, Kahn E, et al. Acute and possible long-co term effects of 1,3-dichloropropene-California. Morbidity and $C$ Mortality Weekly Report 1978;2:50-1.

19 Albrecht WN. Toxicology and hazard assessment of 1,3dichloropropene. Arch Environ Health 1987;42:292-6.

20 Hausler M, Lenich R. Effect of chronic occupational allyl $\frac{T}{0}$ chloride exposure. Arch Toxikol 1968;23:209-14. (In Ger- $\underset{\mathbb{D}}{\mathrm{D}}$ man.)

21 Ali-Zade GA. Renal function in workers exposed to some $\frac{\rho}{\mathbb{D}}$ chemical substances (allyl chloride and metallic mercury). Gig $\varrho$ Tr prof Zabol 1979;10:22-5. (In Russian.)

22 Boqin L, Shwei D, Airu Y, et al. Studies on the toxicity of allyl $<$ chloride. Ecotoxicol Environ Safety 1982;6:19-27.

23 Sram RJ, Cerna M, Kucerova M. The genetic risk of epichloro-응 hydrin as related to the occupational exposure. Biol $\mathrm{Zbl}$ 1976;95:451-62.

Accepted 5 June 1989 